Volume 11 Number 1, January-March 2017: pp. 65-84. Copyright (c) 2015-2016 FIAT JUSTISIA. Faculty of Law, Lampung University, Bandarlampung, Lampung, Indonesia. ISSN: 1978-5186 | e-ISSN: 2477-6238.

Open Access: http://jurnal.fh.unila.ac.id/index.php/fiat

Fiat Justisia is licensed under a Creative Commons Attribution 4.0 International License, which permits unrestricted use, distribution, and reproduction in any medium, provided the

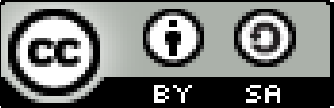
original work is properly cited.

\title{
Restorative Model: \\ the Alternative Justice Response to the Victims of Sexual Violence
}

\author{
Mohamad Ismail Bin Mohamad Yunus \\ Department of Legal Practice, Ahmad Ibrahim Kulliyyah of Laws, \\ International Islamic University Malaysia \\ smailmy@iium.edu.my
}

\begin{abstract}
It is seen there is no proper repositioning of the victims of sexual crimes since the process of contrarian justice is only concerning the sexual offender. Alternative justice models for victims of sexual crimes by involving them in the judiciary process result is necessary to do. However, there is a command from the court for an offender in indemnification though recompensing judgment by Criminal Procedure Code is legitimated. Examining compensation for the victim and urging a legitimated system as alternative justice models for sexual criminal crimes are the aims of this study. The legitimated system as alternative justice which will be recommended in this article is mechanism suitable for justice administration in Malaysia. Through recompensing as well as indemnification, it is considered as a model that can make an impact in restorative justice as the response of alternative justice. Victim Compensation Scheme (VCS) is aimed to be formed and applied with the control of the Criminal Procedure Code too.
\end{abstract}

Keywords: Response of Alternative Justice, Sexual Force Victims

\section{A. Introduction}

Restorative justice is a contemporary approach in the fields of victimology and criminology. Acknowledging that crime causes injury to people and the community, restorative justice insists that those injuries have 
to be repaired and that the injured parties are permitted to participate in the process. Restorative justice programs, therefore, have been designed to enable the victim, the offender and other affected members of the community to be directly involved in the legal prosecution of the crime.

In the case Rex $v$ Grondkowski, ${ }^{1}$ Lord Goddard L.C.J. observed ${ }^{2}$ :

"The judge must consider the interests of justice as well as the interests of the prisoners. It is too often nowadays though, or seems to be thought that the interest of justice means only the interests of the prisoners."

Justice has become central to the criminal justice process, with governmental and legal professionals serving as facilitators of a system that aims at offender accountability, reparation to the victim and full participation by the victim, offender, and community. ${ }^{3}$

In the Brunei case of Taib Bin Gemokv Public Prosecutor, ${ }^{4}$ Justice Rhind adequately explains why imprisonment alone as punishment should not be considered in certain cases; he held that:

"In terms of penalties for criminal offences, a maximum sentence of 6 months" imprisonment and a fine of $\$ 1,000 /$ - is indicative that the legislature does not regard an offense as being one of high order of gravity, and for such an offense it would normally only be in a situation where there were aggravating circumstances that a court would take the step of sending an offender, particularly a first offender, to prison. For offenses under this section, a prison sentence should be the exception, at least for first offenders. In the present case, a sentence of imprisonment was wholly in principle. A fine of \$250/- should be substituted for the term of imprisonment, and the appellant should be disqualified from

${ }^{1}$ (1946) 1 All ER, pp. 560-561.

2 Ibid.

3 Vienna Declaration on Crime and Justice: Meeting the Challenges of the Twenty-first Century, 10th United Nations Congress on the Prevention of Crime and the Treatment of Offenders, Vienna, 10-17 April 2000, A/CONF. 184/4/Rev. 3, para. 29. See also, Hakimah Bt.Yaacob. "The Analysis on the Rights of Rape Victims in Malaysia." (2012). Ph.D Thesis. International Islamic University Malaysia, pp. 168-191; The "The Bangkok DeclarationSynergies and Responses: Strategic Alliances in Crime Prevention and Criminal Justice", 11th United Nations Congress on the Prevention of Crime and the Treatment of Offenders, Bangkok, 18-25 April 2005, para. 32. Note also that, in 2001, the European Union issued a framework decision stating that member states should promote mediation in criminal cases and bring into force their legal instruments by 2006. See European Union Council Framework Decision of 15th of March 2001 on the Standing of Victims in Criminal Proceedings, Article 10.

4 (1984) 1 MLJ 313. 
applying for licenses to drive any class of vehicle for a period of 12 months." 5

Furthermore, he says:

"The modern tendency in sentencing, as I understand it, is not to try to fill the jails at every conceivable opportunity, but only to send people to prison where this is essential in the interest of society. I certainly do not regard it as in the interest of society to send people previously of good character, particularly young people, to prison when there are other adequate means of dealing with them." 6

The above quote is one, which the prosecution must be in a position to comprehend, at all material times, when it approaches the appellate bench.

In Attorney General"s References (Nos 120, 91 and 119 of 2002), ${ }^{7}$ it can be read:

"In all cases of sexual interference, whether amounting to rape or not, it was necessary to take into account all the degree of harm to the victim; the level of the offenders' culpability; and the level of risk to society posed by the offenders. In all classes of sexual offenses, it was also necessary to deter others from acting similarly. Moreover, before passing a lighter sentence because the offenses were stated, the court should weigh the impact on the victim". 8

Similarly, in PP $v$ Loo Choon Fatt, PP $v$ Loo Choon Fatt, ${ }^{9}$ the High Court decided:

"President and Magistrate are often inclined quite naturally to be over-sympathetic to the accused. This is a normal psychological reaction to the situation in which the lonely accused is facing an array of witnesses with authority. The mitigation submitted by the convicted person will also normally bring up problems of family hardship and the other usual problems of living. In such a situation the courts might perhaps find it difficult to decide as to what sentence should be imposed so that the convicted person may not be further burdened with additional hardship. This is my view is a wrong approach. The correct approach is to strike a balance, as far as possible, between the interests of the public and interests of the accused." 10

\footnotetext{
${ }^{5}$ Ibid., p. 134.

${ }^{6}$ Ibid., p. 135.

${ }^{7}$ (2003) 2 ALL ER 955.

${ }^{8}$ Ibid., p. 57.

${ }^{9}$ (1976) 2 MLJ 256.

${ }^{10}$ Ibid., p. 257.
} 
To the same effect, Lord Goddard L.C.J in Rex $v$ Grondkowski, ${ }^{11}$ offered valuable and insightful advice when he said:

"The judge must consider the interest of justice as well as the interest of the prisoners. It is too often nowadays, though, or seems to be thought, that the interests of justice mean only the interests of the prisoners." 12

In $R v$ Ball, ${ }^{13}$ Hilbery $\mathrm{J}$. stressed the importance of striking a balance between public interest and the interests of the convicted offender when he explained:

"In deciding the appropriate sentence, a court should always be guided by certain considerations. The first and foremost is the public interest. The criminal law is publicly enforced, not only with the object of punishing crime but also in the hope of preventing it. A proper sentence, passed in public, serves the public interest in two ways. It may deter others who might be tempted to try crime as seeming to offer easy money on the supposition, that if the offender is caught and brought to justice, the punishment will be negligible. Such a sentence may also deter the particular criminal from committing a crime again, or induce him to turn from a criminal to an honest life. The public interest is indeed served, and best served if the offender is induced to turn from criminal ways to honest living. Our law does not, therefore, fix the sentence for a particular crime, but fixes a maximum sentence and leaves it to the court to decide what is, within that maximum, the appropriate sentence for each criminal in the particular circumstances of each case. Not only regarding each crime but regarding each criminal, the court also has the right and the duty to decide whether to be lenient or severe". ${ }^{14}$

In Tan Bok Yeng v PP, ${ }^{15}$ Sharma J. had occasion to state:

"It is not merely the correction of the offender which is the prime object of punishment. The considerations of public interest also have to be borne in mind. In certain types of offenses, a sentence has got to be a deterrent so that others who are like-minded may be restrained from becoming a menace to society". ${ }^{16}$

Thus, from the above obiter, it is noted that the concept of restorative justice supposedly originated in connection with victim-offender

\footnotetext{
11 (1946) 1 ALL ER 560, 561.

${ }^{12}$ Ibid.

13 (1951) 35 Cr. App. R. 164.

${ }^{14}$ Ibid., p. 167.

15 (1972) 1 MLJ 214.

${ }^{16}$ Ibid., p. 215.
} 
reconciliation programs introduced in Ontario, Canada in the $1970 \mathrm{~s}^{17}$. These programs were the first to mediate directly between victims and offenders. Like the victim-offender mediation programs, which arose in the United States soon after, the focus, was on arriving at resolving the existing conflict of holding offenders personally accountable for their behavior and providing opportunities for offenders to take responsibility for their actions. These programs usually involved only the victims and the offenders who would meet with a mediator on separate sessions.

Victims have criticized the mediation approach on two grounds. Firstly, victims tended to resent the implication that both parties needed to give away ground to reach a negotiated agreement and resolve the conflict caused by the offense as if both parties and not only that of the offenderdeserved and were expected to accept a shared degree of blame. Secondly, victims realized that the focus of these programs lays in defending the interests of the offender, most often at the calculated expense of the victim. Victims felt their role reduced to that of an object of the offender"s reflections when confronting his or her culpability while little effort was being made to repair the harm that had been suffered. In short, the offenders reaped most benefits from these programs while the victims found themselves on the giving side. Indeed, some researches suggested that when reparation and offender diversion from the court system was sought within this single forum, the victim almost always lost out because diversion tended to override all other existing goals. ${ }^{18}$

Important progress has been made in restorative justice in addressing these concerns raised by the victims. Interestingly, new approaches were discovered by adopting elements of traditional practices of dispute resolution and the restoration of victims and offenders, mainly in Canada and New Zealand.

In Canada, a new form of "circle sentencing" emerged during the 1980 s as a First Nations method of responding to offenders and is now exercised in some northern communities. Offenders, victims, their families, and other community members meet in a circle to discuss the circumstances that led to the crime. This practice is built on principles of mediation, indigenous peacemaking processes and consensus decision making (Stuart

17 Marshall, T. and Merry, S. Crime and Accountability: Victim/Offender Mediation in Practice. London: HMSO, (1990), p. 54. See also Maxwell, G.; and Morris, A. (1996). "Research on Family Group Conferences with young offenders in New Zealand", in Hudson, J.; Morris, A.; Maxwell, G. \& Galaway, B., (eds). Family Group Conferences: Perspectives on Policy and Practice. Leichhardt: The Federation Press, p. 174.

${ }^{18}$ Marshall, T. and Merry, S. Op.Cit., p. 59. 
1996). However, circle sentencing has been criticized because its operation depended too much on mainstream court processes and personnel. ${ }^{19}$

In New Zealand, ${ }^{20}$ much more far-reaching reforms were introduced in 1989, which profoundly affected the way in which juvenile justice was administered. The central feature of these reforms was the establishment of family group conferences (FGC) as the primary mechanism for dealing with almost all youth crimes, including very serious offenses. Those family group conferences consist of meetings, which are not limited to young offenders and their victims, but also their wider families. It is based on traditional Maori ways of resolving disputes and dealing with criminal offenses within their community. These group conferences have become entrenched in mainstream criminal justice processing for all New Zealand youth who "decline to deny" their offense, and the program has been extended to some adults as well. ${ }^{21}$

19 Prairie, C. La, "Altering course: new directions in criminal justice and corrections: sentencing circles and family group conferences", Australian and New Zealand Journal of Criminology, Special Issue: Crime, Criminology and Public Policy, (1995), pp. 78-99.

${ }^{20}$ Maxwell, G.; and Morris, A. (1996). "Research on Family Group Conferences with young offenders in New Zealand", in Hudson, J.; Morris, A.; Maxwell, G. and Galaway, B. (eds), Family Group Conferences: Perspectives on Policy and Practice. The Federation Press: Leichhardt.

${ }^{21}$ In November 2009, the First World Congress on Restorative Juvenile Justice (Congress)organised by the Foundation Terre des Hommes, the Public Prosecutor of Peru, the Pontificia Universidad Católica of Perú and the Association Encuentros-Casa de la Juventud-was held in Lima, Peru. The nearly 1000 conference participants represented 63 countries and various groups such as governments, the judiciary, non-governmental organizations, and professional groups working with children. Five Congress objectives guided the deliberations:

1. to reflect upon the concept of restorative juvenile justice and to undertake a critical viabilityanalysis;

2. to examine the methodology and instruments of restorative juvenile justice;

3. to evaluate the situation of the victim in restorative juvenile justice and the need for her/his protection and reparation of damages;

4. to exchange experiences and lessons learned and good practices of restorative juvenile justice worldwide;

5. to elaborate and present some recommendations for the development and implementation of restorative juvenile justice.

The Lima Declaration reflects the deliberations and proposes a series of recommendations for promoting, developing, and implementing restorative practices as an integral part of juvenile justice. Retrieved from http://www.restorativejustice.org/RJOB/limadeclaration /

21 Marshall, T, Restorative Justice: An Overview. London: Home Office Research Development and Statistics Directorate, (1999), p. 5.

${ }^{21}$ Zehr, H, Changing Lenses: A New Focus for Crime and Justice. Scottsdale, Pennsylvania; Waterloo, Ontario: Herald Press, (1990), p. 181. 


\section{B. Analysis And Discussion}

\section{Definition Of Restorative Justice}

Restorative justice is a theory of justice that emphasizes specifically on rectifying the harm caused or revealed by acts of criminal behavior. It is best accomplished through cooperative processes whereby all parties affected by a particular offense come together to resolve collectively how to deal with the aftermath of the offense and its implications for the future. ${ }^{22}$ Viewed through a restorative justice lens, "crime is a violation of people and relationships. It creates obligations to make things right. Justice involves the victim, the offender, and the community in a search for solutions which promote repair, reconciliation, and reassurance". ${ }^{23}$

In short, restorative justice is a process through which remorseful offenders accept responsibility for their misconduct to those parties they have injured and to the community which in response allows the reintegration of the offender into the community. The emphasis is on restoration: restoration of the offender regarding his or her self-respect, restoration of the relationship between the offender and his or her victim, as well as restoration of both offenders and victims within the community. ${ }^{24}$

The definition of restorative justice is balancing the community, the victims, and the offenders need as a way to give a response in the behavior of the criminal. It is a growing concept which has given improvement to dissimilar rendition and coating. The introducing of various terminologies is caused by the difficulties of good and proper translating the concept into dissimilar languages and cultures. ${ }^{25}$

A restorative process can be defined as any process in which victims and offenders as well as the participation and cooperation of other social communities affected by crime to solve their conflict with facilitators' assistance. The United Nations has termed a restorative justice program "any program that uses restorative processes and seeks to achieve restorative outcomes." The emphasis in this definition lies in participatory processes designed to achieve the desired outcome, "participatory" meaning a process

\footnotetext{
${ }^{22}$ Marshall, T. Op.Cit., p. 6.

${ }^{23}$ Zehr, H. Op.Cit., p. 182.

${ }^{24}$ Haley, J. "Crime Prevention through Restorative Justice: Lessons from Japan." In Restorative Justice: International Perspectives, edited by Galaway, B.; and J. Hudson. Monsey, NY; Amsterdam, The Netherlands: Criminal Justice Press and Kugler Publications, (1996), p. 352.

${ }^{25}$ Strang, H. "Restoring victims: an international view", paper presented at the Restoration for Victims of Crime Conference convened by the Australian Institute of Criminology in conjunction with Victims Referral and Assistance Service and held in Melbourne, September 1999.
} 
whereby the victims actively participate in the resolution of the conflict and the recognition of their injuries.

A "restorative process" is defined as "any process in which the victim and the offender, and, where appropriate, any other individuals or community members affected by a crime, participate together actively in the resolution of matters arising from the crime, generally with the help of a facilitator Restorative justice process and the outcome have similar importance. "Parties" is referring to any persons participating in the process. A technique that is commonly used in Europe and many places in the universe which is different from legitimate adjudication is called "mediation." 26

Based on primary legitimate principles, "a restorative outcome" is a mutual arrangement as a restorative process result. It is including the restorative, indemnification and community service which intend to meet the needs of personal and social service with parties responses, and also reaching victim and offender recovering.

Restorative justice holds that "criminal behavior is primarily a violation of one individual by another. When a crime is committed, it is the victim who is harmed, not the state; instead of the offender owing a "debt to society" which must be expunged by experiencing some form of stateimposed punishment, the offender owes a specific debt to the victim who can only be repaid by making good the damage caused." 27 What exactly constitutes "appropriate reparation" is decided through a process of negotiation involving not only the offender and the victim but the respective families and social networks who have also been harmed by the offense. In contrast, the current models adopted in most Asian countries including Malaysia reflect only strictly retributive and rehabilitative aims. Restorative models, however, offer a comprehensive approach which integrates the element of repairing harm which serves the interests of the victims primarily and in consequence those of the offenders and the community at large.

\footnotetext{
${ }^{26}$ See European Council, Recommendation No. RR (99) 19 of the Committee of Ministers to Member States Concerning Mediation in Penal Matters, (1999), p. 111.

${ }^{27}$ Zehr, H. Op.Cit., p. 183.
} 
Table 1: Differences between Restorative, Retributive, and Rehabilitative Models.

\begin{tabular}{|c|c|c|c|}
\hline Focus & $\begin{array}{c}\text { Retributive } \\
\text { model }\end{array}$ & $\begin{array}{c}\text { Rehabilitative } \\
\text { model }\end{array}$ & Restorative model \\
\hline Means & Punishment & Treatment & Repairing \\
\hline Object & $\begin{array}{c}\text { Moral and } \\
\text { juridical balance }\end{array}$ & Rehabilitation & Healing the harm \\
\hline $\begin{array}{c}\text { Victim's } \\
\text { placement }\end{array}$ & Secondary & Secondary & Central \\
\hline $\begin{array}{c}\text { Evaluation } \\
\text { criteria }\end{array}$ & Just desert & $\begin{array}{c}\text { Conforming } \\
\text { behavior }\end{array}$ & Parties satisfaction \\
\hline Context & State power & Welfare State & $\begin{array}{c}\text { Community } \\
\text { Empowerment }\end{array}$ \\
\hline
\end{tabular}

The ultimate aim of restorative justice is that of healing in the sense of repairing harm. Through receiving appropriate reparation, the harm done to the victim can be redressed. Furthermore, by taking responsibility for and making amends to the damage caused, the offender can be reconciled with the victim and reintegrated back into his/her social and familial network. By way of the successful reconciliation and reintegration, community harmony can also be restored." ${ }^{28}$ A definition of restorative justice includes the following fundamental elements: First, crime is understood as a conflict between individuals, which has resulted in injuries inflicted upon a victim, the community, and ultimately to the offender him/herself. Secondly, the criminal justice process aims at restoring peace and harmony in the community, which is only successfully achieved by reconciling all involved parties and repairing the suffered injuries. Thirdly, criminal justice facilitates the active participation of the victims who communicate with their offenders and their communities to find solutions to the conflict." 29

Restorative justice allows for a comprehensive response to criminal behavior which aims at restoring the losses suffered by crime victims and to

\footnotetext{
28 Wundersitz, J. and Hetzel, S. "Family Conferencing for Young Offenders: The South Australian Experience." In Family Group Conferences: Perspectives on Policy \& Practice, edited by Hudson, J. et al. New York: The Federation Press, Inc. and Criminal Justice Press, (1996), pp. 113-114.

${ }^{29}$ Galaway, B. and Hudson, J, Criminal Justice, Restitution and Reconciliation. Monsey, New York: Criminal Justice Press, (1990), p. 2.
} 
facilitate reconciliation and peace among opposing parties ${ }^{30}$. It provides an alternative framework for understanding and responding to crime. Crime is accurately understood and responded to as harm inflicted on certain individuals and the community rather than simply a violation of abstract laws against the state. Those parties most immediately affected by crime namely the victims, community members, and the offenders - are allowed and encouraged to play an active role in the justice process. The current system of criminal justice limits and restricts itself to offender punishment, but it is the restoration of the emotional and material losses resulting from the crime, which are far more important. ${ }^{31}$

\section{Principles Of Restorative Justice}

Restorative principles can be categorized into four key value groups:

1. Encounter: It creates opportunities for victims, offenders, and community members who volunteer to meet and discuss the crime and its aftermath.

2. Amends: It expects offenders to take steps to repair the harm they have caused.

3. Reintegration: It seeks to restore victims and offenders as a whole, contributing members of society.

4. Inclusion: It provides opportunities for parties with a stake in a specific crime to participate in its resolution.

In some cases, it is clear that restorative justice is not the same as current criminal justice. The first one, crime defined as a mere behave of lawbreaking is viewed as crime less than the criminal behavior. The second one, more parties involved in giving the response to the crime. It can be concluded that the aim is different, it concerns recovering and making presentations much better than focusing on the punishment.

Restorative justice is not merely a program but an entirely new way of looking at crime. It is more comprehensive and constructive than the established punitive justice system because it forms a response to crime that focuses on restoring the losses suffered by victims. It holds offenders directly and personally accountable for the harm they have caused to others and forces offenders to participate in rebuilding peace within their community actively. Those affected directly by the crime are enabled to face each other and come to terms with the impact it had on their lives. Victims

\footnotetext{
${ }^{30}$ Minor K.I. and Morrison, J.T, “A Theoretical Study and Critique of Restorative Justice.” In Restorative Justice: International Perspectives, edited by Galaway, B. and New York, J. and Hudson, Amsterdam. Criminal Justice Press and Kugler Publications, (1996), p. 117.

${ }^{31}$ Umbreit, M, "Avoiding the Marginalization and "McDonaldization" of Victim-Offender mediation: A Case Study in Moving Toward the Mainstream", Restorative Juvenile Justice: Repairing the Harm of Youth Crime, edited by Bazemore, G. and Walgrave, L. New York: Criminal Justice Press, (1999), p. 213.
} 
are allowed to play a more active role in the process and are empowered by it. Offenders also benefit because the process requires them to recognize the harm they have caused to their victims and their families, and also to themselves and their own families.

The making of reparation to the victims and the community is a way of liberating themselves from their crime; a sort of liberation, which the common justice system does not provide.

The Vienna Declaration on Crime and Justice: Meeting the Challenges of the Twenty-first Century $(2000)^{32}$ encouraged the "development of restorative justice policies, procedures, and programs that are respectful of the rights, needs, and interests of victims, offenders, communities and other parties." In August 2002, the United Nations Economic and Social Council adopted a resolution calling upon member states implementing restorative justice programs to draw on a set of "Basic Principles on the Use of Restorative Justice Programs in Criminal Matters" (from now on named Basic Principles) developed by a group of experts group. In 2005, the Declaration of the Eleventh United Nations Congress on the Prevention of Crime and the Treatment of Offenders (2005) urged member states to recognize the importance of further developing restorative justice policies, procedures, and programs that include alternatives to prosecution. Restorative justice programs help reduce the burden on the criminal justice system, divert cases out of the system and provide the system with a range of constructive sanctions.

\section{Benefits of Restorative Justice Programmes}

Restorative justice programs allow victims to openly express their thoughts and emotions related to the crime and the harm arising from it. Such programs offer a variety of settings in which victims, offenders, and communities can address and repair the harm caused in a particular case. Since the goal of the process is repairing harm and restoring relationships, victims are given an important voice in making things right. Many victims have expressed high levels of satisfaction with the justice system after having participated in such programmes.

Involvement may also help victims heal emotionally in the aftermath of the crime, as well as reduce the fear of the offender and future victimization. However, these restorative programmes are usually timeconsuming and can be emotionally taxing. For some victims, even the idea of meeting the offender can be overwhelming, and victims who are not ready

\footnotetext{
${ }^{32}$ Handbook on Restorative Justice Programmes, New York: United Nation Series Criminal Justice Handbook Series, (2006), p. 43.
} 
yet to face a confrontation may become distressed if pressured to participate in such programs. ${ }^{33}$

\section{Objectives Of Restorative Justice}

The objectives of restorative justice programs contain the following key elements. These objectives are extracted from a handbook on restorative justice issued by the United Nations. ${ }^{34}$

1. Giving support to victims, let them speak up what they need and assist them in taking part in the resolution process. The system has been focusing more on the victims' needs and interest since two decades ago. In 1985, the General Assembly adopted a Declaration of Basic Principles of Justice for Victims of Crime and Abuse of Power, ${ }^{35}$ which stated, "Informal mechanisms for the resolution of disputes, including mediation, arbitration, and customary justice or indigenous practices, should be utilized where appropriate to facilitate conciliation and redress for victims." The restorative model gives support to victims to be more active and get involved in decision making, and also the victims can get fair and respect treatment as well as restoration and redress. By participating in the decision-making, victims have a say in determining what would be an acceptable outcome for the process and can take steps toward closure. ${ }^{36}$

2. Reconciliation is the focus of restorative justice. It is not only concerning the criminal behavior but the more important thing is peacemaking, dispute resolution, and rebuilding relationship. The

\footnotetext{
${ }^{33}$ Lacey, N. "Community in legal theory: idea, ideal or ideology?, Studies in Law, Politics and Society 15, Westport, Connecticut: JAI Press, (1996), pp. 105-46; see also Lacey, N. and Zedner, L. (1995). "Discourses of community in criminal justice", Journal of Law and Society, 23(3): 301-25; see Maxwell, G. (1999). "Researching Re-Offending", in Morris, A.; and Maxwell, G. (eds), Youth Justice in Focus: Proceedings of an Australasian Conference held 27-30 October 1998 at the Michael Fowler Centre, Wellington. Wellington: Institute of Criminology, Victoria University of Wellington; Narayan, U. "Appropriate responses and preventative benefits: justifying censure and hard treatment in legal punishment". Oxford Journal of Legal Studies, 13(2), (1993), 166-82.

${ }^{34}$ Anonim, Handbook on Restorative Justice Programmes. United Nation Series Criminal Justice Handbook Series. New York. (2006).

35 Refer to www.undocuemtns.gov. See also Hirsch, A. and Narayan, U. (1993). "Degradingness and intrusiveness", pp. 80-87; see Walgrave, L. (1995). "Restorative Justice for Juveniles: Just a Technique or a Fully Fledged Alternative?". The Howard Journal 34, pp. 228-49; see also Walgrave, L. and Aertsen, I. (1996). "Reintegrative shaming and restorative justice: interchangeable, complementary or different?" European Journal on Criminal Policy and Research 4, pp. 67-85.

${ }^{36}$ Ibid., see also Roche, D. (2002). Rise and Risks of Restorative Justice, Oxford: Oxford University Press, p. 26; see also Roche, D. (2002). Accountability in Restorative Justice, Oxford: Oxford University Press, p. 43.
} 
method is viewed primarily for achieving justice, identifying underlying the cause of crime and also developing crime prevention.

3. The objective of the restorative justice is to criticize a criminal act since it has been the primary objective of criminal law for centuries. Somehow, the way to criticize is more positive and flexible that remains the necessity of the process. It is not only about the rules but also the condition of the victims and the offender. ${ }^{37}$

4. The restorative process is aimed to assist the offender in taking the responsibility and consequences easier. It needs active acknowledgment from all parties which participate in the process, to encourage personal responsibilities for the crime.

5. Restorative process concerns the individual that is being harmed more than emphasizing the rule and the punishment as the result of the criminal behavior. A restorative justice process does not necessarily rule out all forms of punishment (e.g., fine, incarceration, probation), but its focus remains firmly on restorative, forward-looking outcomes. The restorative outcome that is being pursued is the repair, as far as possible, of the harm caused by the crime by providing the offender with an opportunity to make meaningful reparation. Restorative justice is relationship-based and strives for outcomes that satisfy a wide group of stakeholders. ${ }^{38}$

6. Identifying factors that lead to crime and informing authorities responsible for crime reduction strategy. The restorative process is an open one that encourages frank discussion of the background of the offense in a spirit of explanation rather than making excuses. If, for

\footnotetext{
${ }^{37}$ General Assembly resolution 40/34 of 29 November 1998, para 7.

${ }^{38}$ In the Gladue case, the Supreme Court of Canada rejected the view that a restorative approach is a more lenient approach to crime, or that a sentence focusing on restorative justice is a lighter sentence. Restoring harmony involves determining sentences that respond to the needs of the victim, the community, and the offender. Along with crime prevention initiatives, to respect for the law and maintenance of a just, peaceful and safe society by imposing sanctions that have one or more of the following objectives:

1. to denounce unlawful conduct;

2. to deter the offender and other persons from committing offences;

3. to separate offenders from society where necessary;

4. to assist in rehabilitating offenders;

5. to provide reparations for harm done to victims or to the community; and

6. to promote a sense of responsibility in offenders, and acknowledgement of the harm done to victims and to the community.

Retrieved from The Church Council on Justice and Corrections - www.ccjc.ca, Restorative Justice Online-www.restorativejustice.org and Correctional Service of Canada - Dispute Resolution Unit - www.csc-scc.gc.ca
} 
example, this reveals that offenders come from areas with particular deficits, action can be taken to remedy the problem. ${ }^{39}$

\section{Models And Programmes In Restorative Justice}

Restorative justice believes that it is in the best interests of society to support offenders in turning away from crime and learning to behave in socially acceptable ways. Restorative programs are designed to encourage offenders to express remorse, to recognize the harm they have done to their victims, and to accept responsibility for their actions. ${ }^{40}$ The programs are as follows:

1. Victim-offender mediation

2. Family or community group conferencing

3. Peacemaking or sentencing circles

4. Restitution

5. Community service

6. Victim, offender \& community meetings

7. Compensation.

\section{Victim-Offender Mediation}

The mediation process between victim and offender can take place during the immurement of the offender which can be the moment for rehabilitation to him/her. The reconciliation program is designed to make sure that the offender is responsible for criminal behavior. ${ }^{41}$

\footnotetext{
${ }^{39}$ Refer to sec 718.2(e) of the Criminal Code which states that "all available sanctions other than imprisonment that are reasonable in the circumstances should be considered for all offenders, with particular attention to the circumstances of Aboriginal offenders".

${ }^{40}$ Mark S. Umbreit is a world-renowned facilitator of Victim Offender Mediation and author of "Restorative Justice through Victim Offender Mediation: A Multi Site Assessment". Western Criminology Review 1(1), retrieved from http://wcr.sonoma.edu/v1n1/morris.html, pp. 1-18 on 13 October 2008. See also Daly, K. (2000). "Restorative justice in diverse and unequal societies", in Law in Context (in press); Daly, K. and Immarigeon, R. (1998). "The Past, Present, and Future of Restorative Justice: Some Critical Reflections", Contemporary Justice Review 1(1): 21-45; see also Daly, K.; and Kitcher, J. (1999). "The (r)evolution of Restorative Justice through Researcher-Practitioner Partnerships", Ethics and Justice. 2(1), retrievable online at www.ethics-justice.org/v2n1; Daly, K.; Venables, M.; McKenna, M.; Mumford, L.; and Christie-Johnston, J. (1998). "South Australia Juvenile Justice (SAJJ) Research on Conferencing", Technical Report No. 1: Project Overview and Research Instruments. School of Criminology and Criminal Justice. Brisbane, Queensland: Griffith University, retrievable online at www.aic.gov.au/r justice .

${ }^{41}$ Ashworth, A. (1986). "Punishment and Compensation: Victims, Offenders and the State", Oxford Journal of Legal Studies, 6(1): 86-122. See also Ashworth, A. (1993). "Some Doubts about Restorative Justice", Criminal Law Forum 4, pp. 277-99; Bargen, J. (1996). "Kids, Cops, Courts, Conferencing and Children"s Rights: A Note on Perspectives", Australian Journal of Human Rights, 2(2): 209-28.
} 
The facilitator is needed to assist the mediation between victim and offender. With the help of a facilitator, they can meet both directly or separately, make them try to listen to each other and express what they feel. So that, an understanding and agreement can be reached. ${ }^{42}$

If the mediation seems to prefer to sentencing, the mediation can be forwarded to court to provide victims' needs safely. If mediation occurs before sentencing, a conciliation agreement between the offender and the victim can be forwarded to the court and acknowledged in the sentence or the conditions of a probation order. This is a process that provides an interested victim the opportunity to meet his or her offender in a safe and structured setting outside the courtroom and supported by the assistance of a trained mediator.

\section{Family or Community Group Conferencing}

This form of conferencing brings together the victim, offender, and family, friends and other key players of both parties to decide how to resolve issues arising in the aftermath of the crime. The aim is to give the victim an opportunity to involve him or herself directly, to increase the offender's awareness of the impact of the crime and take responsibility for it. Such a process engages the offenders' support system in making amends, shaping the offender's future behavior, and allowing the offender and the victim to connect to key community support. Family or community conferencing was adapted from Maori traditional practices operated out by the New Zealand social services department and further modified for the Australian police. ${ }^{43}$

\section{Peacemaking or Sentencing Circles}

Peacemaking circles are designed to reach a workable consensus among community members, victims, victim supporters, offenders, offender supporters, judges, prosecutors, the defense counsel, police and court workers on an appropriate sentencing plan which addresses the concerns of all parties. All parties taking part in the peacemaking circles are hoped to reach a workable consensus. Community Justice Committee (CJC) formation has managed to do this. Sentencing can be the best example

\footnotetext{
${ }^{42}$ Ibid.

${ }^{43}$ It is now practiced in North America, Europe and South Africa in one of the two forms. It has been used with juvenile offenders (most New Zealand juvenile cases are handled by conferencing) and with adult offenders. Research on such programs has reflected a very high degree of satisfaction expressed by victims and offenders -- with the process and the results. See Charlton, R. (2000). Dispute Resolution guidebook. LBC Information Services, p. 12.
} 
of all members participation that is involved in giving responsibility to criminal behavior. ${ }^{44}$

The common objective of the members of the CJC is to find more constructive ways of responding to conflicts arising in their community. The circles' purpose is to heal all parties that are affected by the crime, give a chance to the offender to improve and also let all parties shared responsibility in getting the constructive resolution address underlying causes of criminal behavior, and build a sense of community around shared community values. Circles were adapted from certain Native American traditional practices and are being practiced throughout North American states.

Table 2: Differences between Criminal Court System and Sentencing Circles

\begin{tabular}{|c|c|}
\hline $\begin{array}{l}\text { Differences between the } \\
\text { circles }^{45}\end{array}$ & iminal court $s$ \\
\hline Criminal court & Sentencing circles \\
\hline 1. The conflict is the crime & $\begin{array}{l}\text { 1. The criminal incident is regarded } \\
\text { as a small part of a larger conflict }\end{array}$ \\
\hline $\begin{array}{l}\text { 2. The sentence resolves the } \\
\text { conflict }\end{array}$ & $\begin{array}{l}\text { 2. The sentence is a small part of the } \\
\text { solution }\end{array}$ \\
\hline 3. Focuses on past conduct & $\begin{array}{l}\text { 3. Focuses on the present and future } \\
\text { conduct }\end{array}$ \\
\hline $\begin{array}{l}\text { 4. Takes a narrow view on } \\
\text { behavior }\end{array}$ & 4. Takes a wider, holistic view \\
\hline $\begin{array}{l}\text { 5. Aims at the offender } \\
\text { apologizing }\end{array}$ & 5. Focuses on social conflict \\
\hline $\begin{array}{l}\text { 6. Avoids broader concern with } \\
\text { social conflict }\end{array}$ & $\begin{array}{l}\text { 6. The result is least important- the } \\
\text { process is most important as the } \\
\text { process shapes and sometimes } \\
\text { heals the relationships among all } \\
\text { parties }\end{array}$ \\
\hline
\end{tabular}

${ }^{44}$ Brown, H. And Marriot, A. ADR Principles and Practice. $2^{\text {nd }}$ edition. London: Sweet Maxwell, (1999), p. 12.

45 Adapted from Griffiths and Cunningham, Canadian Criminal Justice: A Primer. 2nd edition. Toronto: Thomson Nelson, (2003), p. 212. 
7. The result (i.e., the sentence) 7. Empowers the community is most important

8. Relies on professionals

From the above table, we can infer that the sentencing circle centers more on the aspect of healing and is less concerned about "winning" or "losing" as the conventional court system. It empowers the community and the parties to be involved in the process.

\section{Restitution}

Restitution means the payment of a sum of money rendered by the offender to compensate the victim for the financial losses caused by the crime. The approach to view a crime from a restorative perspective holds offenders accountable for their wrongdoing and attempts to repair the victim's injuries. Restitution can be determined by way of mediation, conferencing or circles or following a judge's order. It thus promises a potentially restorative outcome that may result from either a restorative or a conventional process. Studies have shown that restitution increases victim satisfaction with the justice process. Some studies have also shown that it can be associated with the reductions in recidivism. When restitution is determined in the process of mediation, victims were more likely to receive payments compared to payments demanded via court order.

\section{Community Service}

Since community service is understood any work performed by the sentenced offender for the strict benefit of the community. It is justified from a restorative perspective as a viable man to reflect and address the harm a crime has inflicted upon the community. However, it can also be viewed as a simultaneous means of rehabilitating the offender. What distinguishes the use of community service as a restorative response is an attention given to identifying the particular harm suffered by the community as a result of the offender"s crime, and also the effort it involves to ensure that the offender"s service repairs the particular harm he or she has caused. This, of course, applies more readily in cases where a crime has caused physical harm to the community in general rather than a specific individual. For example, offenders who spray graffiti on neighborhood buildings can be asked to remove the same graffiti as community service. Malaysia has applied community service sentencing after deciding the amendment of s 293(1)(e) 
of the Criminal Procedure Code in April 2007. It is hoped that community service programs in Malaysia would be able to address the community concerns and facilitate the offender"s reintegration into the community in cases where such sentencing is deemed most suitable.

\section{The victim, offender, and community meetings}

Meetings between victims, their offenders, and members of the affected community are useful ways to address the relational dimension of crime and justice. It is accepted that the following three methods are hallmarks of restorative justice. Each requires that the offender admit responsibility for the offense. Each is limited to parties who volunteer to participate.

\section{Compensation}

Under compensation is understood any payment made by the State to the crime victims. Victim compensation is defined as a formal procedure mandated by the law which provides the payment of determined sums of money to victims to recompense them for the expenses they have been forced to bear as a direct result of their victimization. According to the Declaration of Basic Principles of Justice for Victims of Crime and Abuse of Power, in cases where compensation is not fully available from the offender or other sources, it becomes the State's responsibility to pay compensation to (a) victims who have sustained significant bodily injury or impairment of physical or mental health as a result of serious crimes; and (b) the family, in particular dependents of persons who have died or become physically or mentally incapacitated as a result of such victimization. The first victim compensation programme was introduced in New Zealand in 1963, followed by Great Britain in $1964^{46}$. The first U.S. victim compensation program was established in California in 1965, followed by New York, Hawaii, Massachusetts, Maryland, and the Virgin Islands ${ }^{47}$.

Other English-speaking countries like Australia and Canada introduced such programs in 1967 and Ireland in $1968^{48}$. In the 1970s, the first European countries established compensation programmes ${ }^{49}$, such as

\footnotetext{
${ }^{46}$ For further details, see Blagg, H. (2002). "A Just Measure Shame: Aboriginal Youth Conferencing in Australia". British Journal of Criminology, 37(4): 481-502. See also Coates, U.R. (2001). Victim Impact of Meeting the Young Offenders: Two Decades of Victim Offender Mediation Practice and Research”. Oxford: Hart Publishing, pp. 121-143.

${ }^{47}$ Ibid.

48 Ibid.

${ }^{49}$ Ibid.
} 
Sweden in 1971, Austria in 1972, Finland in 1975, Holland in 1975, Germany, Norway and Denmark in 1976, and France in $1977 .{ }^{50}$

\section{Conclusion}

The concept of restorative justice needs to receive more consideration in drafting legal policies, procedures, and programmes that are respectful of the rights, needs, and interests of victims, offenders, communities and all other parties involved. As compared to rehabilitative and retributive models, the restorative model centers more on repairing and healing the harm inflicted in the course of a crime. It focuses on community empowerment rather than the limited punishment of the offender and the physical treatment of the victim. Restorative justice does not merely constitute a viable way of reforming the criminal justice system but a way of transforming the entire legal system, family lives, conduct in the workplace, the practice of politics. Its vision is to accomplish a holistic change in the way we do justice in the world. Restorative justice can ensure that the rights of crime victims, and in particular, rape victims, are truly guaranteed.

\section{A. Book}

\section{Bibliography}

Charlton, R. (2000). Dispute Resolution guidebook. London: LBC Information Services.

Coates, U.R. (2001). Victim Impact of Meeting the Young Offenders: Two Decades of Victim Offender Mediation Practice and Research, Oxford: Hart Publishing.

Daly, K. and Immarigeon, R. (1998). "The past, present, and future of restorative justice: some critical reflections." Contemporary Justice Review. 1(1): 21.

Daly, K. and Kitcher, J. (1999). The revolution of restorative justice through researcher-practitioner partnerships. Ethics and Justice.

Daly, K.; Venables, M.; McKenna, M.; Mumford, L.; and Christie-Johnston, J. (1998), "South Australia Juvenile Justice (SAJJ)" Research on Conferencing, Technical Report No. 1: Project Overview and Research Instruments. School of Criminology and Criminal Justice: Griffith University, Brisbane, Queensland.

Haley, J. (1996). "Crime Prevention Through Restorative Justice: Lessons from Japan." In Restorative Justice: International Perspectives, edited by Galaway, B., and Hudson, Monsey, J. New York; Amsterdam, The Netherlands: Criminal Justice Press and Kugler Publications.

${ }^{50}$ Ibid. 
Lacey, N. (1996). "Community in legal theory: idea, ideal or ideology?", Studies in Law, Politics and Society 15, Connecticut: JAI Press, Westport: N. Lacey and L. Zedner. (1995). "Discourses of community in criminal justice." Journal of Law and Society, 23(3): 301.

Marshall, T. (1999). Restorative Justice: An Overview. London: Home Office Research Development and Statistics Directorate.

Marshall, T. and Merry, S. (1990). Crime and Accountability: Victim/Offender Mediation in Practice. London: HMSO.

Minor, K.I. And Morrison, J.T. (1996). "A Theoretical Study and Critique of Restorative Justice." In Restorative Justice: International Perspectives, edited by Galaway, B. and New York, J. and Hudson, Amsterdam. Criminal Justice Press and Kugler Publications.

Narayan. (1993). "Appropriate responses and preventative benefits: justifying censure and hard treatment in legal punishment." Oxford Journal of Legal Studies, 13(2): 166.

The "The Bangkok Declaration-Synergies and Responses: Strategic Alliances in Crime Prevention and Criminal Justice," 11th United Nations Congress on the Prevention of Crime and the Treatment of Offenders, Bangkok, 18-25 April 2005, para. 32.

Umbreit, M. (1999). "Avoiding the Marginalization and "McDonaldization" of Victim-Offender Mediation: A Case Study in Moving Toward the Mainstream," in Restorative Juvenile Justice: Repairing the Harm of Youth Crime, edited by G. Bazemore and L. Walgrave, New York: Criminal Justice Press.

Umbreit, Mark S. (2008). "Restorative justice through Victim-Offender Mediation: A Multisite Assessment". Western Criminology Review: 1.

Walgrave, L. and Aertsen, I. (1996). "Reintegrative shaming and restorative justice: interchangeable, complementary or different?" European Journal on Criminal Policy and Research: 4.

Wundersitz, J. and Hetzel, S. (1996). "Family Conferencing for Young Offenders: The South Australian Experience." In Family Group Conferences: Perspectives on Policy \& Practice, edited by Hudson, J. et al. New York the Federation Press, Inc. and Criminal Justice Press. 